\title{
Spory wokół Trybunału Konstytucyjnego w Polsce w latach 1981-1985*
}

Prehistoria sporów na temat samego istnienia i kształtu sądu konstytucyjnego w Polsce sięga, co prawda, lat 70. ubiegłego wieku' ${ }^{1}$, ale dyskusja na temat dopuszczalności jego istnienia w państwie socjalistycznym rozpoczęła się już dekadę wcześniej². Jednak tą sprawą ze szczególną intensywnością zajęto się dopiero w latach 1981-1985. W okresie tych czterech lat powołano przecież do istnienia Trybunał Konstytucyjny, spierając się na początku, czy ma być to odrębny organ państwowy, a później dyskutując na temat jego ustroju, kompetencji i sposobu funkcjonowania.

* W artykule tym po części korzystam z ustaleń poczynionych w pracy L. Mażewski, Wiele hałasu o nic? Konflikt wokót Trybunatu Konstytucyjnego w latach 2015-2016, Warszawa-Radzymin 2017.

${ }^{1}$ Por. L. Mażewski, rozdz. VIII.1; idem, Dtuga dekada lat siedemdziesiatych (1968-1981). Rola nowelizacji z 10 lutego 1976 r. Konstytucji PRL z 22 lipca w ewolucji ustroju PRL na tle konstytucji europejskich państw socjalistycznych, Torun 2011, rozdz. 3.3. Szczególne znaczenie miał tu artykuł F. Siemieńskiego, Problem kontroli konstytucyjności ustaw w państwie socjalistycznym, „Ruch Prawniczy, Ekonomiczny i Socjologiczny", 1972 z. 4.

2 W 1961 r., w trakcie zjazdu katedr prawa konstytucyjnego, odbyła się dyskusja nad kontrolą konstytucyjności ustaw w państwach zachodnich. Warto pamiętać, iż wówczas Marek Sobolewski - bodajże jako pierwszy w polskiej nauce prawa - wysunął tezę, iż instytucja ta, po jej gruntownym przekształceniu, mogłaby być zastosowana z pożytkiem w państwie socjalistycznym [w:] J. Ziembiński, Sesja naukowa katedr prawa konstytucyjnego, „Państwo i Prawo”, 1961, nr 12, s. 1054), co przełamywało istotne doktrynalne tabu. 


\section{KONGRES STRONNICTWA DEMOKRATYCZNEGO, IX NADZWYCZAJNY ZJAZD POLSKIEJ ZJEDNOCZONEJ PARTII ROBOTNICZEJ I I KRAJOWY ZJAZD DELEGATÓW NSZZ „SOLIDARNOŚĆ"}

W 1981 r. odbyły się zjazdy SD, PZPR oraz NSZZ „Solidarność”, zaś $\mathrm{w}$ uchwałach programowych przyjętych $\mathrm{w}$ ich trakcie znalazł się postulat powołania sądownictwa konstytucyjnego, acz niekoniecznie w postaci Trybunału Konstytucyjnego jako odrębnego organu państwa. Tak czy owak było to oczywiste novum w sytuacji ustrojowopolitycznej Polski.

W trakcie obrad XII Kongresu SD, który odbył się w Warszawie w połowie marca 1981 r., został przedstawiony program reform ustroju PRL. W Uchwale kongresu SD wyraźny priorytet przyznano powołaniu Trybunału Konstytucyjnego. Czytamy tam: „Kongres zobowiązuje Centralny Komitet do podjęcia działań w celu utworzenia Trybunału Konstytucyjnego"3.

Dokładnie w cztery miesiące po kongresie SD miał miejsce IX Nadzwyczajny Zjazd PZPR. Przyjęta Uchwała programowa zobowiązała Komitet Centralny i Klub Poselski PZPR do „rozważenia zgłaszanego w wielu organizacjach partyjnych wniosku o utworzenie Trybunału Konstytucyjnego lub powierzenie jego funkcji SN i podjęcie odpowiednich inicjatyw ustawodawczych"4.

I wreszcie w kolejne dwa miesiące później doszło do I KZD NSZZ „Solidarność". W Uchwale programowej proponowano powołanie Trybunału Konstytucyjnego (albo też odpowiedniej izby Sądu Najwyższego), którego zadaniem miałoby być orzekanie o zgodności ustaw z Konstytucją oraz zgodności aktów niższego rzędu z ustawami (teza 23 pkt 4). Ponadto głoszono tam: „,badaniu powinna podlegać również zgodność prawa wewnętrznego z ratyfikowanymi konwencjami i Międzynarodowymi Paktami Praw"s.

We wszystkich trzech dokumentach programowych postuluje się ustanowienie w Polsce sądownictwa konstytucyjnego, ale jedynie SD mówi, że chodzi o powołanie do życia Trybunału Konstytucyjnego, zaś PZPR i NSZZ „Solidarność” alternatywnie przedstawiają możliwość przekazania badania konstytucyjności

${ }^{3}$ Uchwała XII Kongresu SD, [w:] Dokumenty i materiaty XII Kongresu SD, Warszawa 1981, s. 55 .

${ }^{4}$ Uchwata programowa IX nadzwyczajnego zjazdu PZPR, „Nowe Drogi”, 1981, nr 8, s. 128. Bogumił Szmulik (Sadownictwo konstytucyjne. Ochrona konstytucyjności prawa w Polsce, Lublin 2001, s. 41) twierdzi, że właśnie ta uchwała była „decydującym impulsem do podjęcia prac nad utworzeniem" TK.

${ }^{5}$ Uchwała programowa z Aneksem. I KZD NSZZ ,,Solidarność”, bd i mw. Nieco szerzej zob. L. Mażewski, Ustrój polityczny i społeczno-gospodarczy Polski w uchwałach I KZD NSZZ „, Solidarność”. Z perspektywy 35 lat, „Przegląd Sejmowy”, 2016, nr 4, s. 211. 
i legalności prawa także nowo powstałej izbie $\mathrm{SN}^{6}$. Właściwie z dokumentów tych nic więcej nie dowiadujemy się na temat proponowanej nowej instytucji prawnokonstytucyjnej, poza tym że NSZZ „Solidarność” proponowała, aby kognicja sądu obejmowała również badanie zgodności prawa wewnętrznego z prawem międzynarodowym. W rezultacie PRL musiałaby przynajmniej przestrzegać ratyfikowanych aktów prawa międzynarodowego.

Śmiało możemy zatem uznać, że wraz z przyjęciem tych trzech dokumentów programowych rozpoczynają się rzeczywiste spory na temat kształtu Trybunału Konstytucyjnego w Polsce. Nie było jednak oczywiste nie tylko to, czy chodziło o istnienie odrębnego organu państwowego, który zajmowałby się kwestią badania konstytucyjności i legalności prawa, ale również, czy na pewno dojdzie do powstanie tej instytucji prawnokonstytucyjnej. Ostatecznie sprawa została rozstrzygnięta w dwu etapach: 26 marca 1982 r. i 29 kwietnia 1985 r. W dodatku przez cały czas trwały spory co do ustroju, kompetencji i sposobu funkcjonowania Trybunału Konstytucyjnego.

\section{NOWELA Z 26 MARCA 1982 R. KONSTYTUCJI PRL}

Jak wiadomo, nowela z 10 lutego 1976 r. Konstytucji PRL (Dz.U. Nr 5, poz. 29) w art. 30 ust. 1 pkt 3 nadała Radzie Państwa kompetencję do czuwania nad zgodnością prawa z konstytucją ${ }^{7}$. Rada Państwa nigdy nie skorzystała z przyznanego jej uprawnienia do kontroli konstytucyjności prawa. Słowem, sprawa kontroli zgodności norm prawnych z Konstytucją została w 1976 r. otwarta na gruncie prawa, ale $\mathrm{z}$ całą pewnością nie znalazła ostatecznego rozwiązana. Zmiana Konstytucji z 26 marca 1982 r. (Dz.U. Nr 11, poz. 83) uczyniła tu krok następny, ustanawiając Trybunał Konstytucyjny i uchylając jednocześnie art. 30 ust. 1 pkt 3. Zanim wniesiono do Sejmu stosowny projekt prawny anonimowa grupa prawników z NRD wydała negatywną ocenę w sprawie powołania nowych instytucji

${ }^{6} \mathrm{~W}$ doktrynie poparli to stanowisko m.in. Z. Wasilkowska (O potrzebach i kierunkach zmian przepisów o Sądzie Najwyższym, „Nowe Prawo”, 1981, nr 4, s. 60) oraz L. Garlicki (Reforma wymiaru sprawiedliwości a kontrola konstytucyjności ustaw, „Państwo i Prawo”, 1982, nr 1-2, s. 4041). Ten ostatni autor podtrzymał swój pogląd także po zmianie konstytucji PRL, czemu dał wyraz w dyskusji zorganizowanej przez „Prawo i Życie”, nr 17/1982. W 10 lat później L. Garlicki (Władza sądownicza a nowa Konstytucja, „Przegląd Sądowy”, 1991, nr 1-2, s. 12) pisał na temat przejęcia przez SN sądowej kontroli konstytucyjności prawa, że „polityka wdarłaby się z kolei do samego Sądu Najwyższego, co mogłoby poważnie zaszkodzić jego niezależności i niezawisłości jego sędziów".

${ }^{7}$ Por. L. Mażewski, System rządów w PRL (1952-1989), Warszawa-Biała Podlaska 2011, rozdz. VIII.2 wraz z cytowaną tam literaturą. 
ustrojowych, chodziło także o Trybunał Stanu ${ }^{8}$, ale nie powstrzymało to ekipy stanu wojennego przed realizacją zalecenia programowego IX Nadzwyczajnego Zjazdu PZPR.

W rezultacie rozstrzygnięto istotny dylemat ustrojowy dotyczący Trybunału Konstytucyjnego: odrębny organ państwowy czy kolejna izba SN, ale nie przesądzało to o rzeczywistym istnieniu tej instytucji, gdyż noweli konstytucyjnej nie towarzyszyło uchwalenie stosownej ustawy zwykłej ${ }^{9}$. Nie bezpodstawne były obawy, że rządzący mogą posłużyć się tu wzorem czechosłowackim. Powołanie sądu konstytucyjnego zapowiedziała ustawa konstytucyjna z 27 października 1968 r. o federacji czechosłowackiej, ale nigdy nie doszło do rzeczywistego powołania tego organu. Nie uchylono też odpowiednich przepisów ustawy konstytucyjnej ${ }^{10}$. W PRL tak się nie stało, ale zanim powstał Trybunał Konstytucyjny i rozpoczął orzekanie, minęło jeszcze kilka lat. Brakowało przede wszystkim ustawy zwykłej o TK. W praktyce oznaczało to, że spór o kształt sądownictwa konstytucyjnego jest daleki od rozstrzygnięcia.

W wyniku marcowej nowelizacji Konstytucji PRL w ustawie zasadniczej znalazło się miejsce dla Trybunału Konstytucyjnego. Bez wątpienia był to owoc ponad dwudziestu lat dyskusji i zabiegów środowiska prawniczego, które najpierw musiało przełamać opór znacznej części doktryny prawa konstytucyjnego (ze Stefanem Rozmarynem i Konstantym Grzybowskim na czele ${ }^{11}$ ), ale również efekt przemian ustrojowopolitycznych, z jakimi mieliśmy do czynienia w PRL po wprowadzenia stanu wojennego z 12 na 13 grudnia 1981 r. ${ }^{12}$.

Mirosław Granat podkreślał, że powołanie TK ,jest osiągnięciem (bodajże największym) nauki prawa konstytucyjnego w minionym pięćdziesięcioleciu (od 1956 r., kiedy prawem państwowym można było już się zajmować)"13; Stanisław Gebethner natomiast trafnie zwrócił uwagę, że „tym spiritus movens, tym głównym czynnikiem, który doprowadził do powołania TK była «Solidarność».

${ }^{8}$ Por. Ocena utworzenia Trybunatu Konstytucyjnego i Trybunatu Stanu w PRL, podaję za M. Granat, Sądowa kontrola konstytucyjności prawa w państwach Europy Środkowej i Wschodniej, Warszawa 2003, s. 94-97.

${ }^{9}$ Szeroko pisze o tym L. Garlicki, Ewolucja ustrojowej roli i kompetencji polskiego Trybunału Konstytucyjnego, [w:] Ksiega XX-lecia orzecznictwa Trybunału Konstytucyjnego, Warszawa 2006, s. 3-4.

${ }^{10}$ Por. E. Zwierzchowski, Europejskie trybunaty konstytucyjne. Zarys rozwiąań konstytucyjnych, Katowice 1989, s. 44-45.

${ }^{11}$ S. Rozmaryn, Kontrola konstytucyjności ustaw, „Państwo i Prawo”, 1948, nr 11 i 12; K. Grzybowski, Stalinizm w socjalistycznym prawie konstytucyjnym, „Państwo i Prawo”, 1957, nr 6, s. 1063.

12 Szerzej zob. L. Mażewski, Władza, własność i położenie Kościoła. Z dziejów autorytaryzmu w Polsce w latach 1944/1945-1989/1990, Toruń 2015, część V.

${ }^{13}$ M. Granat, Trybunat Konstytucyjny. Osiagnięcie czy zadanie? [w:] Trzecia władza. Sądy i trybunaty w Polsce. Materiały Jubileuszowego L Ogólnopolskiego Zjazdu katedr i Zakładów Prawa Konstytucyjnego, Gdynia, 24-26 kwietnia 2008, pod red. A. Szmyta, Gdańsk 2008, s. 24. 
Ale dlaczego? Dlatego, że podważyła kierowniczą rolę partii. Nieważne, że był stan wojenny, czy co się dalej działo. Kierownicza rola partii właściwie przestała funkcjonować, w gruncie rzeczy, w dniu wprowadzenia stanu wojennego, albo jeszcze wcześniej”"14.W wyraźnej kontrze do tych opinii Jerzy Stępień głosi, że zmiany związane z powstaniem Trybunału Konstytucyjnego ,nie były wydarzeniami spektakularnymi" ${ }^{15}$.

Wraz z uchwaleniem przepisów art. 33a konstytucji PRL skreślony został pkt 3 art. 30 ust.1. Utrzymany został jednak pkt 4, z czego wynika, że powszechnie obowiązująca wykładnia ustaw dokonywana przez Radę Państwa „ogranicza w pewien sposób uprawnienia orzecznicze Trybunału i może stanowić podstawę korygowania w przyszłości wykładni, jakiej będzie on dokonywał w swoich orzeczeniach" ${ }^{16}$. Nowelą konstytucyjną z 7 kwietnia 1989 r. (Dz.U. Nr 19, poz. 101) prawo do ustalania powszechnej wykładni ustaw zostało nadane Trybunałowi Konstytucyjnemu, z tym że do uchwalenia pierwszej wykładni doszło już po upadku PRL ${ }^{17}$.

Marcowa nowelizacja ustawy zasadniczej pozwalała odtworzyć konstytucyjny model Trybunału Konstytucyjnego ${ }^{18}$. Utworzony został nowy, samodzielny organ o quasi-sądowym charakterze ${ }^{19}$, powołany wyłącznie do rozstrzygania o konstytucyjności oraz legalności prawa ${ }^{20}$, a nie celowości istnienia jakichś norm prawnych ${ }^{21}$.

${ }^{14}$ S. Gebethner, [w:] ibidem, s. 58.

15 J. Stępień, Lepsze nie zawsze wrogiem dobrego, [w:] Księga XXV-lecia Trybunału Konstytucyjnego, Warszawa 2010, s. 131.

16 Z. Rykowski, W. Sokolewicz, Kontrola konstytucyjności prawa w PRL, „Studia Prawnicze”, 1983, z. 2, s. 62-63.

17 J. Oniszczuk, Orzecznictwo Trybunatu Konstytucyjnego w latach 1986-1996, Warszawa 1998, s. 6.

18 Szczegółowo starali się odtworzyć ten model Z. Rykowski i W. Sokolewicz (Kontrola..., s. 47-63) oraz Andrzej Gwiżdż (Trybunat Konstytucyjny, „Państwo i Prawo”, 1983, nr 12, s. 6-13). W tezach pisali o tym także Z. Czeszejko-Sochacki, Trybunat Konstytucyjny w PRL, Warszawa 1986, s. 49; B. Szmulik, Sądownictwo..., s. 43.

19 Należy zgodzić się z L. Garlickim (Charakter ustrojowy nowych Trybunałów, „Państwo i Prawo”, 1983, nr 3), że Trybunał Konstytucyjny nie stanowił, tak samo zresztą jak Trybunał Stanu, w konstytucyjnym rozumieniu sądu, chociaż nie wszyscy podzielali ten pogląd. F. Siemieński (Trybunat Konstytucyjny (pozycja ustrojowa, właściwość, organizacja i postępowanie), [w:] Kontrola konstytucyjności prawa, opr. M. Granat, R. Mojak, J. Sobczak, Lublin 1987, s. 10) twierdził, iż TK jest to „sąd, ale zarazem sąd szczególnego rodzaju”.

${ }^{20}$ S. Gebethner (Przyszty Trybunat Konstytucyjny, „Życie Warszawy”, 17 II 1982) chciał, aby kompetencje TK obejmowały ponadto $\mathrm{m}$. in. nadzór nad postępowaniem wyborczym w wyborach do organów przedstawicielskich, rejestrowanie i wykreślanie z rejestrów związków zawodowych i rozstrzyganie w sprawie, czy przestrzegają one prawa i Konstytucji, czuwanie nad konstytucyjnymi i ustawowymi uprawnieniami różnego rodzaju samorządów. O tym, że takie uprawnienia miały niektóre inne europejskie sądy konstytucyjne, zob. E. Zwierzchowski, Europejskie..., rozdz. VI.

${ }^{21}$ Wyraźnie to podkreślali Z. Rykowski i W. Sokolewicz, Kontrola..., s. 63-64: „Cele czy zasady ustrojowe - tak, ale tylko wówczas i o tyle, kiedy i o ile zostały uprzednio wyrażone w normach prawnych". Trybunał Konstytucyjny w orzeczeniu z 7 września 1988 r. (Uw. 3/88) potwierdził, iż 
Na mocy art. 33a ust. 1 Konstytucji PRL zadaniem TK było orzekanie o zgodności z Konstytucją ustaw i innych aktów normatywnych naczelnych i centralnych organów państwowych, zaś z ust. 3 wynikało, że ponadto do jego właściwości należało orzekanie w sprawach zgodności innych aktów normatywnych z ustawami.

Posłużono się tu materialnym, a nie formalnym pojęciem aktu normatywnego; zwraca też uwagę, że jedynym aktem prawnym wymienionym z nazwy była ustawa. Stąd właściwość Trybunału została określona bardzo szeroko. Wyraźnie wyłączono z niej jedynie akty organów terenowych, ale nie do końca rozstrzygnięta była kwestia możliwości badania umów międzynarodowych ${ }^{22}$.

Orzeczenia o niezgodności ustaw $\mathrm{z}$ Konstytucją podlegały rozpatrzeniu przez Sejm. Trybunał nie mógł więc samodzielnie pozbawić mocy prawnej ustawy uznanej za sprzeczną z Konstytucją, a jedynie przedstawiał swe stanowisko Sejmowi, do którego należało ostateczne rozstrzygnięcie ${ }^{23}$. Wiążący natomiast charakter miały orzeczenia o konstytucyjności aktów prawnych, w tym ustaw, względnie o niezgodności innych aktów normatywnych z Konstytucją lub ustawami. Trybunał miał też prawo stosowania środków potrzebnych do usunięcia tych niezgodności.

O długości kadencji członków TK wybieranych wyłącznie przez Sejm ${ }^{24}$ oraz o właściwości, ustroju i organizacji postępowania przed Trybunałem miała rozstrzygnąć ustawa.

O praktycznym znaczeniu Trybunału Konstytucyjnego w dużym stopniu decydowało rozstrzygnięcie kwestii - do czego nie odniosła się nowela - czy kontrola TK winna mieć charakter konkretny (zarzut niekonstytucyjności może być podniesiony tylko jako ekscepcja w odniesieniu do normy ustawowej, która ma stać się podstawą rozstrzygnięcia konkretnej sprawy zawisłej przed sądem), czy też abstrakcyjny (zarzut niekonstytucyjności może zostać podniesiony przeciwko ustawie jako takiej, bez związku z toczącym się postępowaniem sądowym). Sformułowany został pogląd, iż na gruncie Konstytucji PRL mieliśmy do czynienia

Konstytucja nie przewiduje możliwości kontroli ustaw i innych aktów normatywnych z jakichkolwiek pozaprawnych punktów widzenia. Dlatego też w orzeczeniu z 19 października $1988 \mathrm{r}$. (Uw. 4/88), Trybunał mógł wyraźnie stwierdzić, że nie ustosunkuje się do racji społeczno-gospodarczych, które legły u podstaw unormowań prawnych, nie jest to bowiem przedmiot jego oceny.

${ }^{22}$ Uwagi w sprawie sposobu, w jakim ustawodawca mógłby unormować kwestię kontroli konstytucyjności umów międzynarodowych sformułowali Z. Rykowski i W. Sokolewicz, Kontrola..., s. $59-60$.

${ }^{23}$ S. Gebethner (Przyszły...) proponował, że jeśli „Sejm uznałby, że względy społeczne i polityczne przemawiają za utrzymaniem rozwiązań w spornej ustawie, to wówczas winien on wnieść odpowiednią poprawkę do Konstytucji i treść tej poprawki poddać pod ogólnonarodowe referendum”. Zatem „głos rozstrzygający winien należeć do ludu”.

${ }^{24}$ Tenże proponował, by 1/3 składu Trybunału wybierał Sejm, 1/3 - Rada Państwa (a najlepiej prezydent, gdyby doszło do utworzenia tego urzędu) oraz 1/3 - kolegium składające się z przedstawicieli SN, NSA i Naczelnej Rady Adwokackiej. 
z modelem kontroli abstrakcyjnej, gdyż „Trybunał nie rozstrzyga sporu o prawo, tj. o zastosowanie prawa do danej sytuacji faktycznej, lecz usuwa sprzeczności między prawami, tj. między aktami niższego a wyższego rzędu"25. Ustawodawca zwykły opowiedział się jednak za nieco innym rozwiązaniem prawnym.

Ważne było również, że organ uprawniony do kontroli ustaw nie miał możliwości podnoszenia zarzutu niekonstytucyjności z własnej inicjatywy, gdyż w przeciwnym razie wystąpić mogłoby wyraźne zachwianie równowagi w systemie władzy publicznej na rzecz przewagi Trybunału Konstytucyjnego. Poza tym takie rozstrzygnięcie bardziej przybliżało Trybunał do modelu sądu konstytucyjnego, który, będąc sądem, z natury rzeczy powinien działać na wniosek, a nie z inicjatywy własnej. Z zachwianiem równowagi w ramach władzy publicznej nie mielibyśmy natomiast do czynienia w sytuacji, gdy kontrola taka byłaby wynikiem ekscepcji obywateli.

Z dotychczasowych rozważań wynika, że marcowa nowela Konstytucji PRL nie rozstrzygnęła wszystkich sporów odnośnie ustroju i kompetencji Trybunału. Bez wątpienia tymi sprawami powinna zająć się ustawa zwykła, o czym mówił art. 33a ust.6, ale póki co jej nie było. Jedna sprawa była jednak oczywista. Ustanowiony 26 marca 1982 r. organ nie był sądem konstytucyjnym, ponieważ jego wyroki w sprawie badania konstytucyjności aktów ustawowych stwierdzające ich niekonstytucyjność nie miały charakteru ostatecznego. Doszło raczej do powołania jakiegoś organu quasi-sądowokonstytucyjnego. Należy szerzej rozważyć tę kwestię ze względu na jej zasadnicze znaczenie ustrojowopolityczne.

\section{TRYBUNAŁ KONSTYTUCYJNY: SĄD KONSTYTUCYJNY CZY ORGAN QUASI-SĄDOWOKONSTYTUCYJNY?}

Z regulacji konstytucyjnej wynikało, że chociaż „Członkowie Trybunału Konstytucyjnego są niezawiśli i podlegają jedynie Konstytucji” (ust. 5), to jednak Sejm w pewnym sensie pozostał organem nadrzędnym wobec Trybunału. Nadrzędność parlamentu wyrażała się poprzez to, że to on określał w drodze ustawy właściwość, ustrój i postępowanie przed TK, jak też w tym, że to wyłącznie on wybierał członków TK (ust. 4) i zapewne w określonych sytuacjach mógł ich odwołać, jakkolwiek nie było to wprost określone w Konstytucji. Z drugiej jednak strony, Trybunał podlegał parlamentowi o tyle tylko, o ile szczegółowe przepisy konstytucyjne, odnoszące się do stosunków między Sejmem a Trybunałem, przewidywały środki i formy takiego podporządkowania. Z ogólnej zasady art. 20 ust. 3 Konstytucji PRL, że Sejm ,sprawuje kontrolę nad działalnością innych or-

25 Z. Rykowski, W. Sokolewicz, Kontrola..., s. 53. 
ganów władzy i administracji państwowej”, żadne uprawnienia parlamentu wobec Trybunału nie wynikały.

Najważniejszą jednak sprawą było, że Trybunał w noweli marcowej nie uzyskał pozycji organu samodzielnie i wiążąco sprawującego kontrolę zgodności ustaw (i zapewne dekretów z mocą ustawy) z Konstytucją, o czym już wspominałem. Orzeczenie TK o niezgodności aktu ustawowego z Konstytucją było rozpatrywane przez Sejm. W takiej sytuacji parlament mógł podjąć jedną z trzech decyzji: uznać orzeczenie za zasadne i dokonać odpowiednich zmian w akcie objętym orzeczeniem bądź uchylić go w części lub całości; uznając orzeczenie za zasadne mógł dokonać odpowiednich zmian przepisów konstytucyjnych, z którymi kwestionowana ustawa miałaby być sprzeczna, co, rzecz jasna, byłoby możliwe w trybie przewidzianym dla zmiany ustawy zasadniczej; i wreszcie mógł uznać ustawę objętą orzeczeniem TK za zgodną z Konstytucją, w takim zaś przypadku oddaliłby orzeczenie Trybunału, zapewne i w tej sytuacji potrzebna byłaby większość konieczna do zmiany Konstytucji.

Zważywszy, że TK nie posiadał prawa do wiążącej oceny zgodności aktów ustawowych z Konstytucją, można uznać, iż koncepcja tego organu nie stanowiła rewolucyjnego zwrotu w zakresie rozwiązań ustrojowopolitycznych w Polsce. Marcowa nowela nie doprowadziła bowiem do ustanowienia instytucji sądownictwa konstytucyjnego, gdyż nie była spełniona jedna z cech wyróżniających tę instytucję, a mianowicie, że „orzeczenia trybunału (konstytucyjnego) mają charakter wiążący i ostateczny"26. Trybunał Konstytucyjny nie był zatem sądem konstytucyjnym rozstrzygającym spór między ustawodawcą zwykłym a konstytucyjnym, chociaż miał prawo wypowiadać się w sprawie takiego sporu. Czym zatem był Trybunał?

Co prawda, nowela marcowa nie przyznała ostatecznego charakteru orzeczeniom TK w sprawie konstytucyjności aktów ustawowych, ale taki charakter miały jego orzeczenia w sprawie konstytucyjności innych aktów prawnych oraz ich legalności, czyli zgodności z ustawą. Stąd istnienie TK mogło „mieć istotne znaczenie dla kontroli nad prawodawstwem administracyjnym i podniesienia efektywności ochrony praw obywateli’"27. Słowem, Trybunał powinien znakomicie wspomagać Naczelny Sąd Administracyjny w staraniach na rzecz zapewnienia prymatu ustawy w systemie źródeł prawa.

Jednak mimo wszystko z punktu widzenia rządzących w wyrażeniu zgody na ustanowienie Trybunału Konstytucyjnego tkwiło spore ryzyko, gdyż orzekałby

${ }^{26}$ L. Garlicki, Sądowa ochrona konstytucji we wspótczesnym państwie kapitalistycznym-Trybunat Konstytucyjny, [w:] Kontrola..., s. 39. Podobnie E. Zwierzchowski, Europejskie.., s. 45-46.

${ }^{27}$ L. Garlicki, Ewolucja polskiego prawa państwowego w latach 1980-1982 (naczelne organy państwowe), Warszawa 1983, s. 36. Tak samo A. Gwiżdż, Trybunat Konstytucyjny..., s. 15. 
on jedynie w oparciu o kryterium konstytucyjności względnie legalności, a nie zgodności z prawnie nieokreślonymi zasadami ustrojowymi czy celami ustroju. Oczywiście podstawą działalności orzeczniczej TK mogły być takie zasady ogólne wyrażone w ustawie zasadniczej, jak zasada socjalistycznego charakteru państwa (art. 1 ust. 1 Konstytucji), ochrony i rozwoju zdobyczy polskiego ludu pracującego (art. 5 pkt 1), rozwoju demokracji socjalistycznej (art. 7) czy przewodniej roli PZPR w budowie socjalizmu (art. 3 ust. 1), ale „być może zresztą, działalność Trybunału przyczyni się do ich dalszego sprecyzowania, a nawet skłoni ustrojodawcę do zastanowienia się nad zmianami w Konstytucji, której obecna stylizacja nie ułatwia - przyznajmy - sądowo lub tylko quasi-sądowo stosowania jej przepisów" ${ }^{28}$. W konsekwencji pojawiał się w ustroju PRL czynnik, którego działalność mogłaby doprowadzić do pewnego ograniczenia dotychczasowej pozycji rządzących, i to bez względu na brak ostatecznego charakteru orzeczenia TK o niekonstytucyjności aktu o mocy ustawy zwykłej.

W konstrukcji prawnej TK oficjalnie przeważyły argumenty na rzecz ochrony najwyższej pozycji Sejmu w systemie władzy publicznej, ale w rzeczywistości szło o coś innego. Wedle Antoniego Dudka, gen. Wojciech Jaruzelski dlatego akceptował ustanowienie nowych rozwiązań ustrojowych, w tym przede wszystkim Trybunału Konstytucyjnego, gdyż „nie będą one zagrażały fundamentom systemu, przyniosą zaś obozowi władzy wymierne korzyści polityczne"29. Jak było w rzeczywistości? Otóż ówcześni rządzący nie chcieli wyrazić zgody, aby ich wola podniesiona do godności ustawy była badana pod względem zgodności z Konstytucją przez jakikolwiek organ, a tym bardziej od nich niezależny. Jeśli jednak już zdecydowano się na takie rozwiązanie, to ostateczna decyzja musiała należeć do gremium pozostającego pod kontrolą rządzących, czyli Sejmu. Zgoda była jedynie na wiążący charakter orzeczeń Trybunału w sprawie badania konstytucyjności i legalności aktów normatywnych Rady Ministrów i innych centralnych organów administracji. W przekonaniu bowiem rządzących taka sytuacja nie zagrażała systemowi ustrojowemu, a mogła podnieść sprawność działania aparatu państwowego. Zapewne tak samo oceniali oni działalność NSA, chociaż odnosili się do sądownictwa administracyjnego ze sporą dozą nieufności, nie dopuszczając m.in. do jego konstytucjonalizacji ${ }^{30}$.

Na gruncie marcowej noweli Konstytucji PRL nie da się uznać Trybunału Konstytucyjnego za sąd konstytucyjny, a co najwyżej może być to organ quasi-sądowokonstytucyjny. Przesądzał o tym przede wszystkim fakt, iż orzeczenia

\footnotetext{
${ }^{28}$ Z. Rykowski, W. Sokolewicz, Kontrola..., s. 63.

29 A. Dudek, Reglamentowana rewolucja. Rozktad dyktatury komunistycznej w Polsce 19881990, Kraków 2004, s. 110-115, szczególnie s. 112.

${ }^{30}$ Zob. L. Mażewski, Dluga..., rozdz. 13.3.
} 
w sprawie konstytucyjności aktów ustawowych nie miały mocy ostatecznej, będąc rodzajem opinii podlegającej rozpatrzeniu przez Sejm. Inaczej rzecz się miała z aktami normatywnymi stanowionymi przez naczelne i centralne organy państwowe. To ostatnie miało oczywiste znaczenie dla wzmacniania prymatu ustawy w systemie źródeł prawa oraz podniesienia efektywności ochrony praw i wolności obywateli.

\section{PRACE NAD USTAWĄ O TRYBUNALE KONSTYTUCYJNYM}

Jak już pisałem, zasadnicze znaczenie dla rzeczywistego istnienia Trybunału Konstytucyjnego miało uchwalenie ustawy, zapowiedzianej w art. 33a ust. 6 Konstytucji PRL. Zanim do tego doszło - powstało czternaście wersji projektu ustawy o $\mathrm{TK}^{31}$. Pierwszy z nich pochodził z 1 marca $1982 \mathrm{r}^{32}$, a więc jeszcze sprzed marcowej nowelizacji Konstytucji PRL. Ostatni projekt z 27 lutego 1985 r. stanowił już inicjatywę poselską do wszczęcia postępowania legislacyjnego w Sejmie. Jak stwierdza B. Szmulik, prace ,nad projektem ustawy koncentrowały się w zasadzie w klubie poselskim PZPR, przy czym główna koordynacja organizacyjna leżała w gestii Biura Prac Sejmowych KC PZPR" "33. Zasadnicze decyzje zapadały jednak na posiedzeniach centralnych instancji partyjnych: Biura Politycznego i Sekretariatu KC PZPR. Świadczyło to o znaczeniu, jakie rządzący przywiązywali do powstania nowej instytucji prawnokonstytucyjnej.

W trakcie prac nad przygotowaniem projektu ustawy kilka spraw miało szczególne znaczenie. Na wstępie chodziło o rozstrzygnięcie, czy Trybunał ma sprawować kontrolę wyłącznie następczą, jak to zostało ostatecznie przyjęte, czy także - w ograniczonym i ściśle ustalonym zakresie - kontrolę wstępną. Dalej zastanawiano się nad celowością poddania kontroli konstytucyjności umów międzynarodowych, czego nie wykluczała nowela konstytucyjna. Ostatecznie jednak zrezygnowano z takiej możliwości. Przedmiotem sporu był też charakter kontroli konstytucyjności prawa: czy wyłącznie abstrakcyjna, czy także konkretna, a jeśli tak, to w jakim zakresie i w jakiej postaci. Jak wiadomo, przyjęto model kontroli abstrakcyjnej, ale z możliwością stosowania kontroli konkretnej, co zapewniała instytucja pytań prawnych. Istotną sprawą było określenie kręgu podmiotów

${ }^{31}$ O pracach nad ustawą o TK zob. Z. Czeszejko-Sochacki, Trybunat Konstytucyjny..., s. 49-65; idem, Przebieg prac nad utworzeniem polskiego Trybunału Konstytucyjnego (1981-1985), „Przegląd Sejmowy", 1994, nr 3; B. Szmulik, Sądownictwo..., s. 44-56. W swoich analizach będę korzystał z poczynionych przez nich ustaleń.

32 Powyższy projekt był efektem pracy Międzyklubowego Zespołu Ekspertów (R. Mojak, J. Sobczak, Prace i dokonania Parlamentarnego Zespolu Ekspertów w latach 1981-1982, „Annales UMCS", Sectio G (Ius), vol. XXXVII, 1990, s. 145-147).

${ }_{33}$ B. Szmulik, Sąownictwo..., s. 44. 
uprawnionych do wszczynania postępowania. Tu pojawił się problem ustanowienia skargi powszechnej (actio popularis) lub skargi konstytucyjnej. Niestety, żadna $\mathrm{z}$ tych instytucji nie znalazła się $\mathrm{w}$ ustawie. Na koniec dyskutowana była kwestia roszczeń z tytułu stosowania przez uprawnione organy niekonstytucyjnej normy prawnej. Nie przyjęto koncepcji stworzenia samodzielnej podstawy odszkodowawczej, zamiast tego ustanowiono podstawę prawną do wzruszania innych postępowań (wznawiania, stwierdzania nieważności itp.) w sytuacji uznania aktu normatywnego za niekonstytucyjny.

Z punktu widzenia możliwości obrony praw i wolności obywatelskich niezwykle istotne było, aby obywatel miał możliwość samodzielnego wystąpienia do TK. Sześć pierwszych projektów przewidywało istnienie skargi powszechnej, aczkolwiek pierwszy projekt dopuszczał taką skargę jedynie wówczas, gdy skarżący obywatel miał „swój interes prawny”. Ten wymóg zbliżał tę propozycję do instytucji skargi konstytucyjnej, a więc przyznania obywatelowi prawa do wniesienia skargi do Trybunału w wypadku, gdy prawomocna decyzja lub orzeczenie naruszy jego konstytucyjnie gwarantowane prawo.

Uzasadniając rezygnację ze skargi powszechnej, nawet przy obwarowaniu jej filtrem w postaci pośrednictwa rzecznika interesu społecznego ${ }^{34}$, Leszek Garlicki pisał, iż jej ustanowienie mogłoby prowadzić do nadmiernego przeciążenia Trybunału i - co ważniejsze - „do orientowania jego działalności na problemy pozostające w luźnym związku z praktyką stosowania prawa" ${ }^{35}$. W trakcie prac Komisji Nadzwyczajnej do rozpatrzenia projektu ustawy o TK pojawiła się propozycja uzupełnienia projektu ustawy o instytucję skargi konstytucyjnej. Za takim rozwiązaniem opowiadał się cytowany już L. Garlicki: „tego typu skarga mogłaby podlegać wstępnej selekcji przez zespół trzech sędziów TK”. ${ }^{36}$ Propozycja ta nie znalazła jednak poparcia.

Przyjęcie modelu kontroli o wyłącznie abstrakcyjnym charakterze spowodowałoby, że obywatel nie będzie miał możliwości podważania konstytucyjności ustawy, która w sposób bezpośredni narusza jego prawa, stając się podstawą rozstrzygnięcia konkretnej sprawy. Kontrola konstytucyjności, która „nie mogłaby służyć bezpośredniej ochronie konstytucyjnych praw obywateli, nie spełniałaby więc swego podstawowego zadania" ${ }^{37}$.

${ }^{34} \mathrm{O}$ takim rozwiązaniu mówił projekt opracowany przez Międzyklubowy Zespół Ekspertów (ibidem, s. 146-147).

${ }^{35}$ L. Garlicki, Trybunat Konstytucyjny ante portas, „Prawo i Życie”, nr 52/1984. Podobnie zresztą uzasadniał w swoim wystąpieniu brak actio popularis poseł-sprawozdawca ustawy o TK W. Zakrzewski (Sprawozdanie stenograficzne Sejmu PRL, kadencja VIII-sesja X, 64 posiedzenie, łam 13).

${ }^{36}$ L. Garlicki, Trybunat Konstytucyjny...

37 L. Garlicki, Reforma..., s. 38. 
Mimo tych wszystkich mankamentów, najważniejszy był fakt doprowadzenia do uchwalenia ustawy o TK. Tym samym Polska nie podzieliła losu Czechosłowacji i stworzone zostały podstawy prawne umożliwiające rzeczywiste istnienie Trybunału Konstytucyjnego.

\section{USTAWA O TRYBUNALE KONSTYTUCYJNYM Z 29 KWIETNIA 1985 R.}

Ustawa o TK została uchwalona 29 kwietnia 1985 r. (Dz.U. Nr 22, poz. 98$)^{38}$. Czy poza konkretyzacją postanowień konstytucyjnych nowa ustawa zawierała jakieś dodatkowe rozwiązania prawne, istotne dla toczących się dotąd sporów wokół Trybunału? Poza sprawami, o których już pisałem, akt ten rozstrzygał jeszcze kilka innych ważnych kwestii.

Art. 1 stanowił, że badanie konstytucyjności odnosi się do aktów ustawodawczych (ustaw i dekretów z mocą ustawy) oraz do innych aktów normatywnych (,aktów ustanawiających normy prawne”), wydawanych przez Radę Państwa, naczelne i centralne organy administracji państwowej oraz inne naczelne i centralne organy państwa (pkt 2). Szeroki zakres przedmiotowy badania konstytucyjności prawa wyraźnie podkreślił w swoim wystąpieniu poseł sprawozdawca Witold Zakrzewski. Jego zdaniem kompetencja Trybunału „dotyczy wszelkich aktów nie mających rangi ustawy, jakkolwiek nazwanych, wydawanych na jakichkolwiek podstawach prawnych, o ile tylko zawierają treści normatywne, a więc zobowiązują adresatów z mocy prawa do określonego, względnie konkretyzowanego w nich zachowania" ${ }^{39}$. Stanowisko to znalazło mocne poparcie w doktrynie ${ }^{40}$ i orzecznictwie samego Trybunału ${ }^{41}$.

Jednak w art. 35 ust. 1 zawarte zostało istotne ograniczenie kognicji Trybunału Konstytucyjnego. Otóż wszcząć postępowanie w sprawie konstytucyjności bądź legalności można było w przypadku aktów prawnych wydanych (zatwierdzonych odnośnie dekretów z mocą ustawy) jedynie po dniu wejścia w życie noweli konstytucyjnej z 26 marca 1982 r. To z pewnością dość drastycznie pomniejszało zakres aktywności orzeczniczej nowego organu badania konstytucyjności i legalności prawa, a tym samym obniżało jego rangę ustrojową.

${ }^{38}$ Obszernego omówienia tego aktu prawnego dokonał B. Szmulik, Sąownictwo..., rozdz. II.

39 Sprawozdanie stenograficzne Sejmu PRL, kadencja VIII-sesja X, 64 posiedzenie, łam 9.

${ }^{40}$ K. Działocha (Pojęcie aktu normatywnego w ustawie o Trybunale Konstytucyjnym, „Studia Prawnicze”, 1989, nr 2-3, s. 57) pisał, iż kompetencji TK nie podlegały jedynie ,umowy międzynarodowe oraz określone akty normatywne prawa wewnętrznego (uchwały Sejmu, akty normatywne terenowych organów władzy i administracji)".

${ }^{41}$ Szczególnie w orzeczeniu z 7 czerwca 1989 r. (U. 15/88) Trybunał wypowiedział się na rzecz materialnego rozumienia aktu normatywnego. 
Generalnie rzecz biorąc w postępowaniu przed TK został przyjęty abstrakcyjny model badania konstytucyjności prawa, ale instytucja pytań prawnych (rozdz. 4) powodowała, iż w pewnym stopniu został uwzględniony również tryb kontroli konkretnej. Otóż w związku z toczącym się postępowaniem administracyjnym, sądowym, arbitrażowym, w sprawach o wykroczenia oraz w sprawach o przestępstwa i wykroczenia skarbowe, należących do właściwości finansowych organów orzekających, do TK mogły być kierowane pytania prawne co do zgodności aktu ustawodawczego z Konstytucją lub innego aktu normatywnego z Konstytucją lub aktem ustawodawczym, jeśli od odpowiedzi na nie zależy rozstrzygnięcie sprawy w takim postępowaniu (art. 10 ust. 1). W takiej sytuacji postępowanie ulegało zawieszeniu do czasu rozstrzygnięcia sprawy zgodności ujętego w pytaniu aktu ustawodawczego z Konstytucją lub innego aktu normatywnego z Konstytucją lub aktem ustawodawczym (ust. 2). Na mocy art. 11 pytanie prawne rozpoznawał TK na zasadach i w trybie przewidzianym dla rozpoznawania wniosków o stwierdzenie zgodności aktów ustawodawczych z Konstytucją oraz innych aktów normatywnych z Konstytucją lub aktem ustawodawczym.

Co prawda, nie ustanowiono instytucji skargi konstytucyjnej lub skargi powszechnej, charakterystycznych rozwiązań prawnych dla konkretnego modelu badania konstytucyjności prawa, jednak istniała pewna możliwość wykształcenia się substytutu skargi. Otóż skoro Trybunał Konstytucyjny mógł wszcząć postępowanie o stwierdzenie niezgodności aktu ustawodawczego z Konstytucją lub innego aktu normatywnego z Konstytucją lub aktem ustawodawczym z własnej inicjatywy (art. 19 ust. 3), a nikt nie zabronił pisania obywatelom skarg i wniosków do TK, to na podstawie ich analizy Trybunał mógłby wszcząć postępowanie, mimo że wyraźnie nie było to uregulowane w ustawie o $\mathrm{TK}^{42}$.

Art. 19 ust. 1 i 20 ust. 1 bardzo szeroko regulowały krąg podmiotów uprawnionych do występowania $\mathrm{z}$ wnioskiem o wszczęcie postępowania przed Trybunałem, ale jednocześnie $\mathrm{z}$ art. 19 ust. 2 wynikało, że w sprawach odnoszących się „do aktów normatywnych dotyczących obronności Państwa i Sił Zbrojnych PRL oraz bezpieczeństwa Państwa występować mogą: Prezydium Sejmu, Rada Państwa, Rada Ministrów oraz Komitet Obrony Kraju”. Widać wyraźnie, że rządzący próbowali $\mathrm{w}$ ten sposób zabezpieczyć swój interes w postępowaniu przed TK, chociaż zwraca uwagę, iż „porządek publiczny” nie został zaliczony do spraw, w których nastąpiło ograniczenie kręgu wnioskodawców.

Marcowa nowela konstytucyjna nie przyznała TK prawa podejmowania postępowania o niekonstytucyjność lub nielegalność z własnej inicjatywy, ale takie uprawnienie nadała mu kwietniowa ustawa. W istotny sposób wzmacniało

${ }^{42}$ Tak Z. Jarosz, [w:] Kontrola..., s. 113. 
to pozycję Trybunału w systemie władzy publicznej, acz nie czyniło go bardziej organem sądowym, o czym już wspominałem, w dodatku w przyszłości mogąc doprowadzić do wyraźnego zachwiania równowagi ustrojowej na rzecz przewagi Trybunału Konstytucyjnego.

Rozstrzygnięty został tryb postępowania z aktem ustawodawczym uznanym przez Trybunał za niekonstytucyjny. Mówił o tym rozdz. 2 ustawy. Orzeczenie o niekonstytucyjności Sejm rozpatrywał na posiedzeniu plenarnym w toku bieżącej lub najpóźniej najbliższej sesji ${ }^{43}$. Jeżeli izba uznała orzeczenie za zasadne, to dokonywała odpowiednich zmian w akcie ustawodawczym bądź uchylała go w części lub całości. W wypadku uznania tego aktu za zgodny z Konstytucją Sejm oddalał orzeczenie TK, a sprawa nim objęta nie mogła być przedmiotem postępowania. Uchwała Sejmu w przedmiocie oddalenia orzeczenia Trybunału zapadała większością 2/3 głosów, w obecności co najmniej połowy ogólnej liczby posłów, a więc w trybie zmiany ustawy zasadniczej.

Co prawda, orzeczenia TK w sprawie niekonstytucyjności lub nielegalności aktów organów administracji państwowej albo uchwał Rady Państwa o charakterze normatywnym były wiążące, ale w art. 8 ust. 2 została przewidziana możliwość złożenia przez organ, który ustanowił takie akty, wniosku o ponowne rozpatrzenie sprawy w trybie przewidzianym w art. 27 ust. 2 i 3 . W przypadku stwierdzenia niezgodności z Konstytucją lub aktem ustawodawczym aktu normatywnego naczelnego organu administracji państwowej uprawnienie to przysługiwało Radzie Ministrów lub jej prezesowi ${ }^{44}$, zaś w przypadku stwierdzenia niezgodności z Konstytucją lub aktem ustawodawczym aktu normatywnego Rady Państwa, jej przewodniczącego lub innego naczelnego lub centralnego organu państwowego nie będącego organem administracji państwowej uprawnienie to przysługiwało Radzie Państwa lub jej przewodniczącemu. I dopiero po rozpoznaniu takiego wniosku przez Trybunał w pełnym składzie i powtórnym stwierdzeniu niekonstytucyjności lub nielegalności zakwestionowany akt prawny tracił moc prawną. Nieco bałamutnie tłumaczył Jerzy Oniszczuk: „ponowne rozpatrzenie sprawy przez Trybunał w pełnym składzie nie ma charakteru środka odwoławczego. Istota tej instytucji polega na powtórnym zbadaniu zgodności z prawem aktu normatywnego objętego orzeczeniem wydanym w składzie zwykłym" 45 .

${ }^{43}$ Ustawa z 29 maja 1989 r. o przekazaniu kompetencji Rady Państwa Prezydentowi PRL oraz innym organom państwowym (Dz.U. Nr 34, poz. 178) dokonała nowelizacji ustawy o TK, nakładając na Sejm PRL obowiązek rozpatrzenia orzeczeń TK w terminie półrocznym.

${ }^{44}$ P. Sarnecki (Kontrola działalności Rady Ministrów przez Trybunat Konstytucyjny, „Krakowskie Studia Prawnicze”, 1987, tom XX, s. 10) pisał: „Ustawa nie wymienia żadnych szczególnych powodów tej swoistej remonstracji; $\mathrm{z}$ pewnością jednak muszą tu zachodzić istotne okoliczności natury prawnej, nie uzasadniające zdaniem Rządu negatywnego orzeczenia Trybunału Konstytucyjnego".

45 J. Oniszczuk, Orzecznictwo..., s. 48. 
W praktyce z wyżej opisaną sytuacją mieliśmy do czynienia tylko jeden raz, o czym nieco szerzej dalej. W innym przypadku wniosek o ponowne rozpatrzenie sprawy przez Trybunał w pełnym składzie nie został uwzględniony. Takie stanowisko zawarte było w postanowieniu TK z 26 października 1988 r. (U. 7/88) Wniosek Prezesa Rady Ministrów z dnia 12 maja 1988 r. o ponowne rozpatrzenie przez Trybunał Konstytucyjny w pełnym składzie sprawy (U. 7/87). Postanowiono pozostawić powyższy wniosek bez rozpoznania.

Art. 14 ust. 1 pkt 4 stwierdzał, iż Sejm odwołuje członka TK, jeśli „,sprzeniewierzył się złożonemu ślubowaniu”. Ustawodawca zrezygnował zatem z „braku rękojmi", znanej chociażby z ustaw o ustroju sądów powszechnych czy o Sądzie Najwyższym, jako przesłanki odwołania członka Trybunału, ale sens ,,sprzeniewierzenia się złożonemu ślubowaniu" był taki sam. Nie byłoby problemu, gdyby decyzja o „sprzeniewierzeniu się ślubowaniu” przez członka Trybunału zapadała w trybie odpowiedzialności dyscyplinarnej (art. 14 ust. 1 pkt 5). A tak rządzący uzyskiwali wpływ, choćby przez samą groźbę zastosowania tej instytucji, na członków TK, co mogło naruszać ich niezawisłość.

Ustawie o TK towarzyszyła uchwała Sejmu z 31 lipca 1985 r. w sprawie szczegółowego trybu postępowania przed Trybunałem Konstytucyjnym (MP, $\mathrm{Nr} 39$, poz. 184). Dopełniała ona reżim prawny funkcjonowania nowego organu państwa, mając już tylko niewielkie znaczenia dla rozstrzygnięcia sporów związanych z badaniem konstytucyjności i legalności prawa w Polsce, bo stało się to wcześniej.

Jest oczywiste, że kwietniowa ustawa nie mogła zmienić modelu Trybunału Konstytucyjnego ustanowionego marcową nowelą konstytucyjną. Przyznanie Trybunałowi przez ustawę możliwości działania z inicjatywy własnej w dużym stopniu wzmacniało jego pozycję w systemie organów władzy publicznej, nie przybliżając jednak do pełnienia roli sądu konstytucyjnego. Ponadto należy pamiętać o ograniczeniu kognicji TK jedynie do aktów prawnych ustanowionych (bądź zatwierdzonych w przypadku dekretów z mocą ustawy) po 26 marca 1982 r. czy utrudnieniu trybu stwierdzania niekonstytucyjności i nielegalności innych aktów prawnych niż o mocy ustawy.

\section{PODJĘCIE DZIAŁALNOŚCI ORZECZNICZEJ PRZEZ TRYBUNAŁ KONSTYTUCYJNY}

Nowela marcowa Konstytucji PRL, kwietniowa ustawa oraz lipcowa uchwała Sejmu wśród wielu sporów i dyskusji stworzyły reżim prawny Trybunału Konstytucyjnego. Do podjęcia przezeń działalności orzeczniczej pozostało jeszcze powołanie pierwszego składu tego organu, co nastąpiło 12 listopada 1985 r. Sejm 
wybrał 12 sędziów, czyniąc prezesem TK Alfonsa Klafkowskiego, zaś Leonard Łukaszuk został wiceprezesem ${ }^{46}$. Zatem tym razem obyło się bez zbędnej zwłoki. 1 stycznia 1986 r. Trybunał Konstytucyjny mógł rozpocząć działalność.

Pierwszą sprawę Trybunał rozpoznał 28 maja 1986 r. $^{47}$, wydając orzeczenie w składzie 3 sędziów, większością 2 do $1^{48}$. Już to pierwsze rozstrzygnięcie stwierdzało nielegalność niektórych przepisów rozporządzenia Rady Ministrów z 16 września 1985 r. w sprawie szczegółowych zasad i trybu oddawania w użytkowanie wieczyste gruntów i sprzedaży nieruchomości państwowych, kosztów i rozliczeń z tym związanych oraz zarządzania sprzedanymi nieruchomościami (U. 1/86), co przyjęte zostało z nieukrywanym zaskoczeniem i dużą niechęcią przez czynniki rządowe, o czym świadczyć może treść oficjalnego komunikatu prasowego ${ }^{49}$. Wystąpienie przez normodawcę o ponowne rozpatrzenie przez Trybunał sprawy w pełnym składzie nie zmieniło stanowiska TK (U. 5/86). W przyszłości, gdy zachodziła sytuacja możliwości orzeczenia niekonstytucyjności lub nielegalności jakiegoś aktu prawnego (lub jego części) organ uprawniony zazwyczaj uchylał ten akt lub dokonywał stosownej nowelizacji, żeby nie spotkać się z negatywnym stanowiskiem Trybunału. Słowem, z punktu widzenia nadziei pokładanych w nowym organie badania konstytucyjności i legalności prawa - jego debiut należało uznać za udany.

Z całą pewnością można stwierdzić, iż mylili się solidarnościowi autorzy, pisząc, iż kontrola konstytucyjności prawa „stanie się w istniejących warunkach najwyżej terenem pozorowanych spraw między niższymi ogniwami administracji a koncesjonowanymi organizacjami społecznymi"50. Od samego początku, stosując szeroką definicję aktu normatywnego, TK podjął się utwierdzania prymatu ustawy w systemie źródeł prawa PRL, a więc tym, do czego został w grun-

\footnotetext{
${ }^{46}$ Sprawozdanie stenograficzne Sejmu PRL, kadencja IX-sesja I, 2 posiedzenie, łam 69-70. O okolicznościach powołania pierwszego składu Trybunału zob. Z. Czeszejko-Sochacki, $W$ oczekiwaniu na pierwszy sktad TK - 1985 rok (wspomnienie), [w:] Trybunat Konstytucyjny. Księga XV-lecia, Warszawa 2001.

${ }^{47}$ Wyrok Trybunału Konstytucyjnego w sprawie U. 1/86 z 28 maja 1986 r.

${ }^{48}$ Zob. F. Rymarz, Zdanie odrębne w przepisach i praktyce orzeczniczej Trybunału Konstytucyjnego, [w:] Konstytucja i gwarancje jej przestrzegania. Ksiegga pamiątkowa ku czci prof. Janiny Zakrzewskiej, Warszawa 1996, s. 166-167.

${ }^{49}$ Orzeczenie Trybunału Konstytucyjnego, „Rzeczpospolita”, 30 V 1986. Jakiś czas potem w swojej glosie wyroku TK U. 1/86 L. Garlicki („Państwo i Prawo”, 1986, nr 9, s. 141) starał się uspokoić rządzących, wskazując, że w tym orzeczeniu „Trybunał złożył swego rodzaju deklarację powściągliwości sędziowskiej, podkreślając, iż powołany jest tylko do rozstrzygania kwestii prawnych, a nie celowości czy sensowności społecznej działań prawodawczych”.

${ }^{50}$ Raport „Polska 5 lat po Sierpniu”, Londyn 1986, s. 41. Po latach w podobnie lekceważący sposób o działalności Trybunału w latach 1986-1989, a szczególnie o jego orzecznictwie, wypowiada się J. Stępień, Lepsze..., s. 133.
} 
cie rzeczy powołany. Ale do tego wcale nie ograniczyło się jego orzecznictwo, gdyż ponadto kilkakrotnie przed upadkiem PRL stwierdził niekonstytucyjność ustawy $^{51}$. Co prawda, wynikało to z jego konstytucyjnych i ustawowych uprawnień, ale chyba mało kto się spodziewał, że Trybunał zechce tak szybko z nich skorzystać, przybliżając się tym samym do bycia sądem konstytucyjnym sensu stricto.

\section{SPORY WOKÓŁ TRYBUNAŁU KONSTYTUCYJNEGO W POLSCE W LATACH 1981-1985}

Powstaniu Trybunału Konstytucyjnego (1982, 1985), nie zaś odrębnej izby SN, towarzyszyły liczne dyskusje, niekiedy wręcz spory, co miało miejsce w latach 1981-1985.

Rozstrzygnięto przede wszystkim, że w przypadku badania konstytucyjności i legalności prawa szło o istnienie samodzielnego organu państwa, jakim był Trybunał Konstytucyjny, poza tym doprowadzono do podjęcia działalności orzeczniczej przez Trybunał, do czego było potrzebne przyjęcie przez Sejm odpowiedniej ustawy oraz dokonanie wyboru sędziów TK. Bez względu na wszystkie ułomności prawne towarzyszące reżimowi prawnemu nowego organu należy uznać to za ważny krok w tworzeniu sądownictwa konstytucyjnego w Polsce. Świadczy o tym również działalność orzecznicza Trybunału z lat 1986-1989.

Zasłaniając się koniecznością zachowania zwierzchniej pozycji Sejmu w systemie organów państwa ustrojodawca ustanowił taki model Trybunału, którego nie można było w pełni uznać za sąd konstytucyjny; powołano raczej organ do badania legalności prawa w celu zapewnienia prymatu ustawy w systemie źródeł prawa. Jednak nawet takie rozwiązanie prawne miało swoje znaczenie z punktu widzenia ochrony praw i wolności obywatelskich.

Trybunał Konstytucyjny stanie się dopiero wtedy w pełni sądem konstytucyjnym, gdy skutkiem kontroli konstytucyjności ustaw będzie uchylenie mocy prawnej całego aktu, względnie jego przepisu. Kontrola ustanowiona w PRL o mocy jedynie opinii nie mogła więc być zaliczona do sądownictwa konstytucyjnego, acz nie wolno negliżować jej znaczenia dla kontynuowania procesu budowy państwa prawa ${ }^{52}$.

\footnotetext{
51 L. Mażewski, System..., s. 62-63.

52 Szerzej zob. L. Mażewski, Władza..., rozdz. XVII.
} 


\section{DISPUTES OVER THE CONSTITUTIONAL TRIBUNAL IN POLAND BETWEEN 1981 AND 1985}

\section{Summary}

The creation of the Constitutional Tribunal (1981, 1985), instead of a separate chamber of the Supreme Court, was accompanied by numerous discussions and sometimes even disputes. The process took place between 1981 and 1985.

It was decided that in case of analyzing whether a law is constitutional and legal, the most important element is the existence of an independent state body such as the Constitutional Tribunal. Moreover, jurisdiction activity was brought into the purview of the Tribunal. In order to achieve this, the Parliament (Polish Sejm) had to enact a proper statutory law and to select judges for the Constitutional Tribunal. However, regardless of all the legal deficiencies which accompanied the legal regime of the new body, it should be considered an important step in the construction of the constitutional judiciary in Poland. The jurisdiction activity of the Tribunal between 1986 and 1989 also attests to that.

The constitutional legislator created such a model of the Tribunal which prevented it from being fully recognized as a constitutional court. The rationale behind this was the necessity of preserving the Parliament's superior position in the system of state bodies. The Tribunal was rather founded as a body to analyze the legality of law in order to ensure the supremacy of constitutional acts in the system of law sources. However, even such a legal solution had its significance from the point of view of protection of civil and political rights as well as of civil liberties.

\section{DIFFÉRENDS AUTOUR DU TRIBUNAL CONSTITUTIONNEL EN POLOGNE DANS LES ANNÉES 1981-1985}

\section{Résumé}

La création du Tribunal constitutionnel (1982, 1985), et pas une chambre séparée de la Cour suprême, s'est accompagnée de nombreuses discussions, parfois même de différends, qui ont eu lieu entre 1981 et 1985 . Surtout, il a été décidé que la chose la plus importante pour assurer un contrôle de constitutionnalité et de légalité des lois est l'existence d'un organe indépendant de l'État, tel que le Tribunal constitutionnel. En outre, il a été équipé du pouvoir de statuer sur toute saisine portée devant ce Tribunal. Afin de réaliser ces objectifs, la Diète a adopté la loi pertinente et a nommé des juges du TC.

Nonobstant tous les défauts juridiques qui accompagnaient le système juridique de cette nouvelle institution, il faut considérer l'établissement du TC comme étape importante dans le processus de création de la justice constitutionnelle en Pologne. Cela ressort également de la jurisprudence du Tribunal dans les années 1986-1989. En prenant comme une excuse la nécessité de préserver la position dominante de la Diète dans le système des organes de l'État, le législateur a établi un modèle du Tribunal qui ne pouvait être pleinement reconnu comme une cour constitutionnelle; au contraire, il a été un organe doté du pouvoir de contrôler la légalité des lois afin d'assurer la primauté d'une loi dans le système des sources du droit. Mais d'autre part, même une telle solution juridique était importante en termes de protection des droits et libertés civils. 